\title{
Response of Soybean [Glycine max L.] Varieties Grown Under Varying Inter Row Spacing in ManaSibu District, Western Oromia, Ethiopia
}

\author{
Dufera Totoba $^{1} \quad$ Zerihun Jalata $^{2 *} \quad$ Gerba Daba $^{3}$ \\ 1.Oromia Agricultural Office, ManaSibu District Branch Office, Ethiopia \\ 2.Department of Plant Sciences, Faculty of Agricultural Sciences, Wollega University, Ethiopia \\ 3.Department of Horticulture and Plant Science, College of Agriculture and Veterinary Medicine, Jimma \\ University, Ethiopia
}

\begin{abstract}
Current decline in soil fertility and inappropriate agronomic practices are among the main factors for low productivity of soybean. Thus, this study was initiated with the aim of investigating the response of varieties and inters row spacing on yield and yield components of soybean. Treatments consisting of $4 \times 4$ factorial combination of soybean variety with inter row spacing was laid out using RCB design with three replications at ManaSibu District, western Oromia, Ethiopia. The findings revealed that the main effect of variety at varying inter row spacing was highly significant $(\mathrm{P}<0.01)$ for number of pods per plant, above ground biomass, grain yield and harvest index. While main effect of variety was also highly significant for hundred seed weight but significant $(\mathrm{P}<0.05)$ for number seeds per pod. While the interaction effect of variety and inter row spacing was also highly significant effect $(\mathrm{P}<0.01)$ on grain yield while significant on number of pods per plant and harvest index. Soybean Variety 'Dhidessa' gave the highest number of pods per plant (78.8) at 50 and $60 \mathrm{~cm}$ inter row spacing as well as maximum hundred grain weight $(18.3 \mathrm{~g})$, grain yield $(3703.7 \mathrm{kgha}-1)$ and harvest index $(58.82 \%)$ at $50 \mathrm{~cm}$ inter row spacing. Generally, it can be concluded that 'Dhidessa' variety gave superior in grain yield at $50 \mathrm{~cm}$ inter row spacing at ManaSibu area and may be also suitable for similar agroecology.
\end{abstract}

Keywords: Soybean, grain yield; plant population, yield components.

DOI: $10.7176 / \mathrm{JBAH} / 10-15-03$

Publication date:August $31^{\text {st }} 2020$

\section{Introduction}

The soybean [Glycine max (L.) Merrill, family Leguminosae, subfamily Papilionoidae] is one of the world's most important legumes in terms of production and trade. It has been a dominant oilseed sources since the 1960s (Smith and Huyser 1987). Soybean is an essential source of mainly protein, oil and micronutrients in human and animal feed in worldwide (Graham et al. 2003) and soybean contains up to $42 \%$ protein (O'Keefe et al., 2015) and up to $22 \%$ oil, which is widely consumed as cooking oil (Popovic et al. 2013). Soybean production in Ethiopia has the productivity of about 2.3 tha $^{-1}$ (CSA, 2019). However, reports indicate that the national average productivity of soybean in Ethiopia is low as compared to its world productivity $(2.8$ tha-1) which is growing linearly for many years (FAOSTAT 2018) presents a challenge due to lack of proper agronomic practices is among major constraints for the low soybean production (Mesfin and Abush 2018).

Plant density is one of the essential agronomic practices as it is a major management variable used in matching crop requirements to the environmental offer of resources (Ferehewiot and Tekalign 2017). Optimizing the plant population and plant geometry of soybean, there is a considerable scope for increasing yield (Awasarmal et al, 2011). A recent study in southwestern Ethiopia on the responses of early and late maturing soybean varieties to planting density showed greater yield and yield components per unit area as plant density increased plants per unit area (Mohammed and Tessema 2011). The dry matter of plant components, harvest index, grain yield per plant and per unit area, and protein content of soybean varieties also changed with variable plant density (Daniel et al. 2012). Moreover, plant population had significant influences number of pods, number of seed per pod, hundred seed weight, biomass yield, and grain yield (Habtamu et al. 2018).

Thus, improving soybean production not only contributes to food consumption but also improves the income and food security of farmers. Though soybean crop has high production potential in west Wollega Zone, Ethiopia, ManaSibu district and the surrounding areas but yet its productivity has been low. Therefore, identifying adaptable high yielding soybean varieties and optimum planting density has been among major constraints in the study area. Hence, the aim of this study was to investigate the performance of soybean varieties under varying inter-row spacing at ManaSibu district, western Ethiopia.

\section{Materials and Methods}

Experimental site: The experiment was conducted at ManaSibu district, Kela Dabus, western Ethiopia during 2019 which is located in west Wollega zone at $601 \mathrm{~km}$ away from Addis Ababa (Figure 1). The site is located at 
latitude of $8^{\circ} 52^{\prime} 51^{\prime \prime} \mathrm{N}$ and longitude $35^{\circ} 13$ ' $18^{\prime \prime}$ E and altitude of 1455 m.a.s.l. It has a warm humid climate with average minimum and maximum temperature of 14 and $30^{\circ} \mathrm{c}$, respectively.

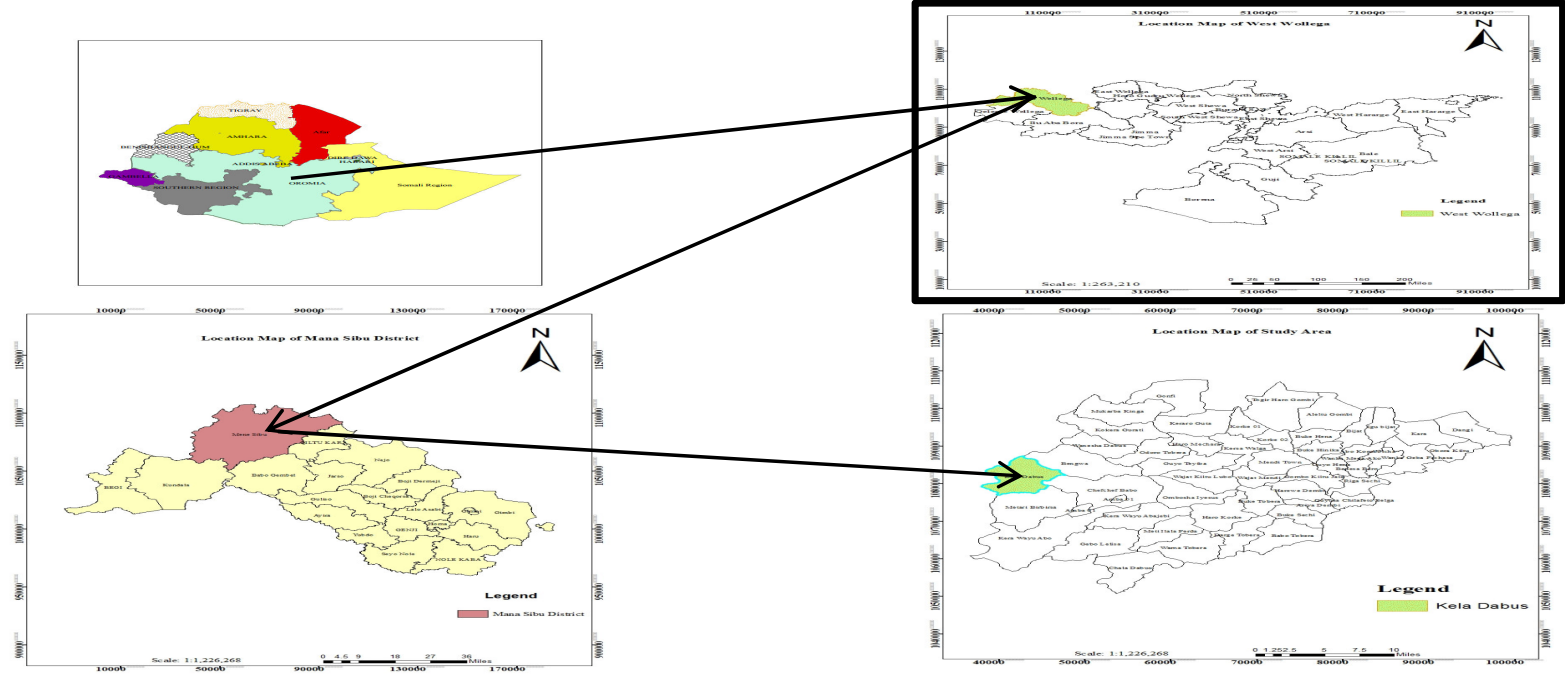

Figure 1: Map of the study area.

The area receives average annual rain fall of 900-1541 $\mathrm{mm}$ and its distribution pattern is unimodal (National Meteorology Agency (2019). The soil of the area is characteristically reddish brown loamy soil with $\mathrm{Ph}$. ranges from 4.2-7 (Nekemte soil laboratory 2018).

Experimental Materials: Newly three soybean varieties 'Dhidessa' (PR-149-81-EP-7-2), 'Cheri' (Ipb-81-Ep7) BARC/OARI and 'Pawe' 03 (TGX-1987-62F) Pawe ARC/EIAR were used during the experiment. The former were medium type in their maturity duration (Table 1). And the local cultivar soybean commonly used by the farmers was included as a control during the experiment.

Table 1.Description of soybean materials used in the study.

\begin{tabular}{llccccccc}
\hline No & Variety & $\begin{array}{c}\text { Year of } \\
\text { release }\end{array}$ & From & $\begin{array}{c}\text { Maturity } \\
\text { group }\end{array}$ & Altitude(m) & $\begin{array}{c}\text { R.F(mm) } \\
\text { Maturity } \\
\text { Day }\end{array}$ & $\begin{array}{c}\text { tha }^{-} \\
\mathbf{1}\end{array}$ \\
\hline $\mathbf{1}$ & Didessa & 2008 & BARC & Medium & $1200-1900$ & $1000-$ & 135 & 2.8 \\
& & & & & 1200 & & \\
$\mathbf{2}$ & Cheri & 2003 & BARC & Medium & $1300-1850$ & $900-1850$ & 137 & 2.1 \\
$\mathbf{3}$ & Pawe 03 & 2016 & AsARC & Medium & $520-1800$ & $460-1600$ & 133 & 2.3 \\
$\mathbf{4}$ & Local & - & Farmers & - & - & - & - & 1.3 \\
& cultivar & & & & & & & \\
\hline
\end{tabular}

Source: MoANR, (2016) and Mesfin and Abush (2018)

Treatment and Experimental Design: The experiment consist two factors of soybean varieties at four levels ['Didessa'(V1), 'Cheri' (V2), 'Pawe' 03 (V3) and local cultivar (V4)] combined with the treatments of inter row spacing at four levels $(30,40,50$ and $60 \mathrm{~cm})$. The experiment was laid out in factorial arrangement using RCBD in three replications. Four different soybean varieties combined with four varying inter row spacing totally 16 experimental treatments which were replicated three times on plot area of $3 \mathrm{mx} 3 \mathrm{~m}$ with $0.5 \mathrm{~m}$ spacing between plots and $1 \mathrm{~m}$ between blocks, respectively. The treatments were assigned to plots at random. The net plot size was $3 \times 16 \times 3 \times 3=432 \mathrm{~m}^{2}$ and the total net area of the experimental field layout $11 \mathrm{mx} 55.5 \mathrm{~m}=610.5 \mathrm{~m}^{2}$. 
Table 2. Description of Treatment Combinations.

\begin{tabular}{|c|c|c|c|c|}
\hline No & Variety & \multicolumn{2}{|c|}{ Inter-Row spacing(IRS) (cm) } & Treatments Combinations \\
\hline 1 & V1 & $30 \mathrm{~cm}$ & IRS1 & V1 and $30 \mathrm{~cm}$ IRS1 \\
\hline 2 & V1 & $40 \mathrm{~cm}$ & IRS2 & $\mathrm{V} 1$ and $40 \mathrm{~cm}$ IRS2 \\
\hline 3 & V1 & $50 \mathrm{~cm}$ & IRS3 & $\mathrm{V} 1$ and $50 \mathrm{~cm}$ IRS3 \\
\hline 4 & V1 & $60 \mathrm{~cm}$ & IRS4 & $\mathrm{V} 1$ and $60 \mathrm{~cm} \mathrm{IRS} 4$ \\
\hline 5 & $\mathrm{~V} 2$ & $30 \mathrm{~cm}$ & IRS1 & $\mathrm{V} 2$ and $30 \mathrm{~cm}$ IRS1 \\
\hline 6 & $\mathrm{~V} 2$ & $40 \mathrm{~cm}$ & IRS2 & $\mathrm{V} 2$ and $40 \mathrm{~cm}$ IRS2 \\
\hline 7 & $\mathrm{~V} 2$ & $50 \mathrm{~cm}$ & IRS3 & $\mathrm{V} 2$ and $50 \mathrm{~cm}$ IRS3 \\
\hline 8 & $\mathrm{~V} 2$ & $60 \mathrm{~cm}$ & IRS4 & $\mathrm{V} 2$ and $60 \mathrm{~cm}$ IRS4 \\
\hline 9 & V3 & $30 \mathrm{~cm}$ & IRS1 & $\mathrm{V} 3$ and $30 \mathrm{~cm}$ IRS1 \\
\hline 10 & $\mathrm{~V} 3$ & $40 \mathrm{~cm}$ & IRS2 & $\mathrm{V} 3$ and $40 \mathrm{~cm}$ IRS2 \\
\hline 11 & V3 & $50 \mathrm{~cm}$ & IRS3 & $\mathrm{V} 3$ and $50 \mathrm{~cm} \mathrm{IRS} 3$ \\
\hline 12 & V3 & $60 \mathrm{~cm}$ & IRS4 & $\mathrm{V} 3$ and $60 \mathrm{~cm}$ IRS4 \\
\hline 13 & V4 & $30 \mathrm{~cm}$ & IRS1 & V4 and $30 \mathrm{~cm}$ IRS1 \\
\hline 14 & V4 & $40 \mathrm{~cm}$ & IRS2 & $\mathrm{V} 4$ and $40 \mathrm{~cm}$ IRS2 \\
\hline 15 & V4 & $50 \mathrm{~cm}$ & IRS3 & $\mathrm{V} 4$ and $50 \mathrm{~cm} \mathrm{IRS} 3$ \\
\hline 16 & V4 & $60 \mathrm{~cm}$ & IRS4 & V4 and $60 \mathrm{cmIRS} 4$ \\
\hline
\end{tabular}

Soybean varieties (V): V1='Dhidessa', V2='Cheri', V3='Pawe' 03 and V4=Local variety.

Field Management and Planting Method: Land preparation was done according to farmers practice in the area (oxen-plough three times) and all experimental plots were prepared as needed and the sowing was done on July 8, 2019. The seeds were planted by hand at a specified spacing by placing seeds per hill at each specific intra row spacing at the depth of 2-5. Uniform dose of recommended Nitrogen, Phosphorous and sulfur (NPS) fertilizer and other management practices were done according to recommended.

Data Collection: data was collected on number of pods per plant, number of seeds per pod, hundred seed weight/plot (g), grain yield $\left(\mathrm{kg} \mathrm{ha}^{-1}\right) /$ plot, above ground dry-biomass per plot (Qt ha $\left.{ }^{-1}\right)$ and harvest index.

Statistical Analysis: Data were subjected to analysis of variance (ANOVA) was performed to analyze the main effects of the two factors (Soybean variety level, inter row spacing) and their interactions using the statistical SAS software version 9.2 (SAS 2004) and the means were cross paired and compared using LSD at 5\% of significance level.

\section{RESULTS AND DISCUSSION}

Plant density affects early ground cover, competitive ability of crops with weed, soil surface evaporation, light interception, lodging and development of an optimum number of fruiting sites in a crop canopy. It also affects canopy development, plant architecture and distribution of pods. Use of proper agronomic practices is one of the important factors which contribute for the increase of yield per unit area (Ferehewiot and Tekalign 2017). In addition to this, there is also varietal difference in response to the environment or plant density due to their genetic variations.

Number of pods per plant: The analysis of variance showed that the interactions of variety and inter row spacing had significant $(\mathrm{P}<0.05)$ effect on the number of pods per plant (Table 3$)$. And the main effect of variety and inter row spacing had highly significant $(\mathrm{P}<0.01)$ effect on the number of pods per plant. The highest mean number of pods per plant (78.8) was recorded for variety 'Dhidessa' at 50 and $60 \mathrm{~cm}$ inter row spacing and the lowest number of pods per plant (41.6) was recorded for local cultivar at $30 \mathrm{~cm}$ inter row spacing (Table 4). The increase in the number of pods per plant with increasing plant spacing may also be due to increase in the number of pods per branches as the result of higher net assimilation rates and reduction of competition in wider spacing.

This result was in line with Dereje (2014), who reported that higher number of pods per plant of soybean varieties at wider inter row spacing $(60 \mathrm{~cm})$ and the lower pods per plant at narrower inter row spacing $(30 \mathrm{~cm})$. Similarly, Kibiru (2018) reported that the highest mean number of pods per plant (49.83) was recorded for variety 'Wello' at $60 \mathrm{~cm}$ inter row spacing and the lowest number of pods per plant (21.67) was recorded for variety 'Nyala' at $30 \mathrm{~cm}$ inter row spacing. Plant population affected pods per plant of soybean, throughout different study, as population increased, pods per plant decreased in a polynomial manner (Epler and Staggenborg 2008). There was a significant effect of plant density on pod number per plant; the pod number increase in the low plant density was as a result of extra branching of soybean (Gulluoglu et al. 2016).

Number of seeds per pod: The main effect of variety and their interaction effect had no significant effect on number of seeds per pod; while, the inter row spacing had significant $(\mathrm{P}<0.01)$ effect on number of seeds per pod (Table 3). Number of seeds per pod is considered an important factor that directly imparts in exploiting potential yield recovery in leguminous crops. This might be due the fact that the number of seeds per pod was primarily regulated by the interaction between the environment and the genotypes. This result conforms to Epler and Staggenborg (2008) report that the number of seeds per pod increased with decreased plant density (wider spacing) 
of soybean which may be associated with increased plant capacity for utilizing the environmental inputs in building great amount of metabolites to be used in developing new tissues and increasing its yield components Almaz and Kindie (2017). Beside this, characteristics; such as number of seeds per pod and 100 seed weight are mostly influenced by genetic factors (Suhre et al. 2014).

Table 3: Analysis of Variance for Yield Components and Yield as affected by soybean varieties and inter row spacing at ManaSibu, Ethiopia in 2019 cropping season.

\begin{tabular}{|c|c|c|c|c|c|c|c|}
\hline \multirow{2}{*}{$\begin{array}{l}\text { Source } \\
\text { of } \\
\text { variation }\end{array}$} & \multirow{2}{*}{$\begin{array}{l}\text { Degree of } \\
\text { freedom }\end{array}$} & \multicolumn{6}{|c|}{ Mean Square } \\
\hline & & PPP & SPP & TAGB & GY & HSW & HI \\
\hline Rep. & 2 & 17.5 & 0.002 & 2934.7 & 21233.98 & 0.7 & 0.88 \\
\hline Variety & 3 & $327.2 * *$ & $\underset{\mathrm{s}}{0.0035^{\mathrm{n}}}$ & $\begin{array}{c}287730.96^{*} \\
*\end{array}$ & $\begin{array}{c}1195573.17 * \\
*\end{array}$ & $\begin{array}{c}132.67 * * \\
*\end{array}$ & $\begin{array}{c}197.38^{*} \\
*\end{array}$ \\
\hline Space & 3 & $\begin{array}{c}1946.7 * \\
*\end{array}$ & $0.02 *$ & $\begin{array}{c}119517.86^{*} \\
*\end{array}$ & $796956.7 * *$ & $0.7 \mathrm{~ns}$ & $97.27 * *$ \\
\hline $\mathrm{V} *$ Space & 9 & $130.8 *$ & $0.006^{\mathrm{ns}}$ & $17618.19 \mathrm{~ns}$ & $132529.4 * *$ & $1.08 \mathrm{~ns}$ & $10.07 *$ \\
\hline Error & 30 & 53.99 & 0.005 & 22029.775 & 30617.1 & 0.97 & 3.42 \\
\hline $\mathrm{CV}(\%)$ & & 9.465 & 2.59 & 5.17 & 6.798 & 6.368 & 3.53 \\
\hline
\end{tabular}

- $\quad \mathrm{PPP}=$ Pod per plant $\mathrm{SPP}=$ Seed Per plant $\mathrm{TAGB}=$ Total Above ground biomass $\mathrm{GY}=$ Grain Yield HSW=Hundred Seed Weight $\mathrm{HI}=$ Harvest Index

Table 4: Interaction effect of variety and inter row spacing on number pods per plant, grain yield $\left(\mathrm{kg} \mathrm{ha}^{-1}\right)$ and harvest Index (\%) of soybean at Mana Sibu District 2019 cropping season.



- Means in columns and rows followed by the same letter(s) are not significantly different at 5\% level of significant; LSD (0.05) = Least Significant Difference at 5\% level; CV=Coefficient of variation.

Hundred grains weight: The main effect of inter row spacing and the interaction of variety and inter row spacing had no significant effect on hundred grains weight of soybean; while the main effect of variety had highly significant $(\mathrm{P}<0.01)$ effect on hundred grains weight (Table 3$)$. Significantly higher hundred grains weight $(18.3 \mathrm{~g})$ was recorded for variety 'Dhidessa' followed by variety 'Cheri' $(16.7 \mathrm{~g})$, local cultivar $(16.5 \mathrm{~g})$ and variety 'Pawe 03' (10.7g) (Table 5). This result was in conformity with the study by Wondimu et al. (2016) who reported that the number of 100 grains weight was significantly affected by main effect of soybean varieties. Similarly, Waswa (2015) stated that inter row spacing did not significantly affect 100 grains weight of soybean genotypes across seasons and sites whereas genotype and season had significant influence on 100 grains weight. 
Table 5: The main effect of variety and inter row spacing on Yield Components and Yield on soybean crop at ManaSibu district in 2019.

\begin{tabular}{lccc}
\hline Variety & SPP & HGW (g) & TAGB (kg ha-1) \\
\hline 'Dhidhessa' & 2.77 & $18.28 \mathrm{a}$ & $2787.03 \mathrm{~b}$ \\
'Cheri' & 2.77 & $16.72 \mathrm{~b}$ & $2796.29 \mathrm{~b}$ \\
'Pawe' 03 & 2.76 & $10.70 \mathrm{~b}$ & $2796.29 \mathrm{~b}$ \\
Local Cultivar & 2.73 & $16.45 \mathrm{c}$ & $3102.77 \mathrm{a}$ \\
\hline LSD (5\%) & NS & $1.65 * *$ & $247.5^{* *}$ \\
CV\% & 2.59 & 6.36 & 5.17 \\
Mean & 2.76 & 15.54 & 2870.59 \\
\hline Row spacing(cm) & & & $3010.18 \mathrm{a}$ \\
\hline 30 & 2.7 & 15.25 & $2847.21 \mathrm{~b}$ \\
40 & 2.7 & 15.72 & $2851.84 \mathrm{~b}$ \\
50 & 2.8 & 15.76 & $2773.14 \mathrm{~b}$ \\
60 & 2.8 & 15.42 & $247.5 * *$ \\
\hline LSD (5\%) & $0.12 *$ & $\mathrm{NS}$ & 5.17 \\
CV\% & 2.59 & 6.36 & 2870.59 \\
Mean & 2.76 & 15.54 & . \\
\hline
\end{tabular}

- Means in column followed by the same letter(s) are not significantly different at $5 \%$ level of significant; $\mathrm{LSD}=$ Least Significant Difference at 5\% level; $\mathrm{CV}=$ Coefficient of variation; ns= Non-significant $\mathrm{SPP}=$ Seed Per plant, $\mathrm{TAGB}=$ Total Above ground biomass, HSW=Hundred Seed Weight

Above ground dry biomass yield: The main effects of variety and inter row spacing had highly significant $(\mathrm{P}<0.01)$ effect on the above ground dry biomass yield $\left(\mathrm{kg} \mathrm{ha}^{-1}\right)$ while the interaction was not significant (Table $3)$. The highest above ground dry biomass $\left(3102.8 \mathrm{~kg} \mathrm{ha}^{-1}\right)$ was recorded for local cultivar and the lowest for variety 'Dhidessa' (2787.0kg ha $\left.{ }^{-1}\right)$ which was not significantly different from variety 'Cheri' (2796.3kg ha') and 'Pawe' $03\left(2796.3 \mathrm{~kg} \mathrm{ha}^{-1}\right)$ (Table 5). The highest biomass yield was from local cultivar which might be due to highest plant height of the local variety than variety 'Dhidessa', 'Pawe' 03 and 'Cheri'; as well as bush (thick stem) and half tailing type of its growing habit. The early and medium maturing genotype had significantly lower biomass than late maturing genotype. The highest above ground dry biomass $\left(3010.2 \mathrm{~kg} \mathrm{ha}^{-1}\right)$ was recorded at inter row spacing of $30 \mathrm{~cm}$ and the lowest biomass $\left(2773.1 \mathrm{~kg} \mathrm{ha}^{-1}\right)$ was recorded at inter row spacing of $60 \mathrm{~cm}($ Table 5$)$. In line with this finding, Nath et al. (2017) indicated dry matter weight is attributed to their genetic potential rather than the effect of external weather parameters in soybean. According to Vanlauwe et al.(2003) high biomass of soybean was obtained in late maturing varieties than in the early maturing.

Grain yield: The main effects of variety and inter row spacing revealed highly significant $(\mathrm{P}<0.01)$ effect on grain yield while the interaction effect of variety and inter row spacing was significant $(\mathrm{P}<0.05)$ on grain yield $(\mathrm{kg}$ $\left.\mathrm{ha}^{-1}\right)$ of soybean (Table 3$)$. The highest grain yield $\left(3703.7 \mathrm{~kg} \mathrm{ha}^{-1}\right),\left(3555.6 \mathrm{~kg} \mathrm{ha}^{-1}\right),\left(3518.5 \mathrm{~kg} \mathrm{ha}^{-1}\right)$ and $(3074.1 \mathrm{~kg}$ $\mathrm{ha}^{-1}$ ) were recorded for variety 'Dhidessa', 'Pawe' 03,'Cheri' and local cultivar; at $50 \mathrm{~cm}, 50 \mathrm{~cm}, 50 \mathrm{~cm}$ and $60 \mathrm{~cm}$ inter row spacing respectively (Table 4). The main difference of grain yield among varieties might be due to difference in seed size (Dugje et al. 2009). Mushoriwa (2013) also stated that soybean grain yield is determined by seed size (100 grains weight) and seed number. And in Keyvan and Kobraee (2012) study also obtained highly significant variation was observed soybean varieties in response to grain yield. Nath et al. (2017) described as seed yield was highly influenced by varieties.

The reason for the difference in interaction effect might be due to response of different varieties of the same crop to different plant spacing because of their growth habit, number of branches per plant and plant height affected by inter row spacing. This result was in line with Dereje (2011) finding who stated that narrow spacing for early maturing variety and wider spacing for medium and late maturing group soybean varieties. In contrast to this, Kolaric et al. (2014) reported that the highest grain yield $\left(4,868 \mathrm{~kg} \mathrm{ha}^{-1}\right)$ was determined at the $20 \mathrm{~cm}$ inter-row spacing and it decreased equally at bigger row spacing (45 and $70 \mathrm{~cm}$ ) for $7.0-12.9 \%$ and the highest grain yield was achieved with 'Balkan' cultivar $\left(4,773 \mathrm{~kg} \mathrm{ha}^{-1}\right)$, and the lowest with 'Dragana' cultivar $\left(4,284 \mathrm{~kg} \mathrm{ha}^{-1}\right)$. Grain yield of soybean was not affected by plant geometry and it ranged from 1.3 to $1.9 \mathrm{t} \cdot \mathrm{ha}^{-1}$ at different spacing (Bhagirath et al. 2014). Other finding by Thandiwe and Schutte (2018) indicate that soybean planted in narrow rows of $19 \mathrm{~cm}$ have higher yield potential when compared to soybean planted in wider rows spacing's $(50-76 \mathrm{~cm})$. Harvest index (\%): Analysis of variance on the harvest index indicated that the main effect of variety and inter row space was highly significant $(\mathrm{P}<0.01)$ and the interaction effect of variety and inter row spacing had a significant effect $(\mathrm{P}<0.05)$ (Table 3). Variety 'Dhidessa' gave the highest harvest index value of $58.8 \%$ at $50 \mathrm{~cm}$ inter row spacing, while local cultivar had the lowest harvest index $41.3 \%$ at $30 \mathrm{~cm}$ inter row spacing, respectively (Table 4) indicating varieties that produce more yield would also produce more harvest index. This was in agreement with Daniel et al. (2011) who reported that harvest index of soybean increased with decreased plant 
density (wider plant spacing) where the highest harvest index (46\%) was from 20 plants per unit area and the lowest harvest index (37\%) was from 50 plants per unit area; which might be due to varietal differences on grain yields and above ground dry biomass of different varieties. Halis et al. (2017) reports showed that the highest and the lowest harvesting index ( 46.3 and $39.5 \%$, respectively) were observed at $70 \mathrm{~cm} \mathrm{x} 10 \mathrm{~cm}$ and $70 \mathrm{~cm} \times 4 \mathrm{~cm}$ spacing, respectively; this indicate harvest index significantly decreased with reducing plant density.

The competition among the plants for absorption of nutrient and photosynthesis become severe and inhibit production and partitioning of food materials resulting tall, thin and slender stems under high planting density (Ohyama et al. 2013). This study was supported by previous findings reported by Daniel et al.(2014) who recorded a highly significant variation among varieties of haricot bean plants that were evaluated for harvest index. In contrast to this result, Habtamu et al. (2018) reported that the main effect of plant population did not show significant variations on harvest index of soybean cultivar. And, Sobko et al. (2019) reported that the main effect of inter row spacing on harvest index was stable characteristic within a cultivar and was not affected by planting density of soybean cultivar.

\section{Conclusion}

The result showed the main effect of variety and inter row spacing was highly significant $(\mathrm{P}<0.01)$ for number of pods per plant, total above ground biomass, grain yield and harvest index. While, main effect of variety and inter row spacing was also highly significant $(\mathrm{P}<0.01)$ for hundred seed weight and significant effect $(\mathrm{P}<0.05)$ for number seeds per pod, respectively. Moreover, the interaction effect of variety and inter row spacing had highly significant effect $(\mathrm{P}<0.01)$ on grain yield but significant on number of pods per plant and harvest index indicating influence of both factors on grain yield. It can be concluded that 'Dhidessa' variety showed superior grain yield performance at $50 \mathrm{~cm}$ inter row spacing at ManaSibu area and may perform in similar agro-ecology of western region.

\section{References}

Almaz Meseret and Kindie Tesfaye (2017).Optimum inter and intra row spacing forfaba bean production under Fluvisols Ethiopian Institute of Agricultural Research, Addis Abeba, Ethiopia CIMMYT, Addis Abeba, Ethiopia MAYFEB Journal Of Agricultural Science-Issn 2371-512x Vol 4(2017)-Pp(10-19)

Awasarmal, A.B, S.B.Soni and S. Diverkar. (2011). Effect of different packaging materials on shelf life of Sapota fruit. International Journal of Processing and Post Harvest Technology;Vol.2 No.2 pp.125-128.

Bhagirath,C., S.Jhoana and L. Opena .(2014).Effect of Plant Spacing on Growth and Grain Yield of Soybean. American Journal of Plant Sciences, 4(10):2011-2014.

Central Statistical Agency (CSA). (2019). Agricultural Sample Survey 2018/2019: Report on Area and Production of Major Crops (Private Peasant Holdings, Meher Season). Volume I, Statistical Bulletin 584, Addis Ababa, Ethiopia.

Daniel, M. U.R. Pal and U. Elias.(2011).Selection of Planting Pattern and Plant Population Density (PPD) for Medium and Late Maturing Soybean Varieties [Glycine max (L.)Merrill] in the Tropics. Innovative Systems Design and Engineering, 2(4): 243-249.

Daniel, M., U.R. Pal, and E.Uragie.(2012). Dry Matter Partitioning, Nodulation and Seed Traits of Medium and Late Maturing Soybean Varieties as Affected by Planting Pattern and Plant Density. Journal of Agricultural Science and Technology 2: 142-150

Daniel, T., A.Teferi, W.Tesfaye and S. Assefa .(2014). Evaluation of improved varieties of haricot bean in West Belessa, Northwest Ethiopia. Int. J. Sci. Res. 3(12):2319-7064.

Dereje, Y.(2014) Response of Soybean [Glycine max (L.) Merrill] Varieties to Plant Spacing in Guliso District, Western Ethiopia. MSc. Thesis in Agronomy, Haramaya University, Ethiopia

Dugje, I.Y., L.O .Omoigui, F.Ekeleme, R. Bandyopadhyay and K. Lava.(2009).Farmers' Guide to Soybean Production in Northern Nigeria. International Institute of Tropical Agriculture, Ibadan, Nigeria; p. 1-21.

Epler, M., and S.Staggenborg. (2008). Soybean yield and yield component response to plant density in narrow row systems. Crop Management, 7(1):1-13.doi: 10.1094/CM-2008-0925-01-RS.

FAOSTAT, (2018). Food and Agriculture Organization of the United Nations Statistics Division. World Production of Barley Grain (http://www.fao.org/faostat/en/\#data/QC/visualize.Data accessed 20 July, 2020).

Ferehewiot Deressegn and Tekalign Telele, (2017). Review on Effects of Inter and Intra Row Spacing on Yield and Yield Components of Soybean (Glycine max (L.) Merrill) in Ethiopia. Journal of Biology, Agriculture and Healthcare, Vol.7(7):53-59..

Graham, P.H, and C.P.Vance. (2003). Legumes: Importance and constraints to greater utilization. Plant Physiology, 131(3): 872-877.

Gulluoglu, Halil Bakal and Halis Arioglu (2016). The Effects Of Twin-Row Planting Pattern And Plant Population On Seed Yield And Yield Components Of Soybean At Late Double-Cropped Planting In Cukurova Region. .Turk J Field Crops 21(1), 59-65 DOI: 10.17557/tjfc.66663. 
Habtamu Deribe, Taye Kufa and Amsalu Nebiyu.(2018). Response of Soybean (Glycine max (L) Merrill) to Plant Population and NP Fertilizer in Kersa Woreda of Jimma Zone, South Western Ethiopia. Int.J.Curr.Res.Aca.Rev. 6(9), 50-71. doi:https://doi.org/10.20546/ijcrar.2018.609.006

Halis, A., L. Gulluoglu, H.l Bakal and A.EL Sabagh .(2017). Soybean Managing For Maximize Production: Plant Population Density Effects on Seed Yield And Some Agronomical traits in Main Cropped Soybean Production in Adana-Turkey. Journal of Experimental Biology and Agricultural Sciences, February - 2017; Volume - 5(1).

Keyvan, S. and S.1 Kobraee .(2012). Effect of Plant Population on Soybean Development and Production. International Conference on Environment, Agriculture and Food Sciences (ICEAFS'2012) August 11-12, 2012 Phuket (Thailand).

Kibiru, K. (2018) Effect of Inter Row Spacing on Yield Components and Yield of Soybean [Glycine Max (L.) Merrill] Varieties in Dale Sedi District, Western Ethiopia. Agri Res\& Tech: Open Access J.; 18(4): 556068. DOI: 10.19080/ARTOAJ.2018.18.556068.

Kolaric, L., L. Zivanovic, V. Popovic, J. Ikanovic and M. Serbric.(2014). Influence of inter-row spacing and cultivar on the productivity of soybean. Biotechnology in Animal Husbandry, 30: 517-528.DOI: 10.2298/BAH1403517K

Mesfin Hailemariam and Abush Tesfaye.(2018).Progress of Soybean [Glycine max (L.) Merrill] Breeding and Genetics Research in Ethiopia: A Review Journal of Natural Sciences Research, 8(13): 201867

Ministry of Agriculture and Natural resource (MoANR).(2016). Plant Variety Release, Protection and Seed Quality Control Directorate. Crop Variety Register, Issue No. 19. Addis Ababa, Ethiopia.

Mohammed Worku and Tessema Astatkie.(2011).Row and Plant Spacing Effects on Yield and Yield Components of Soybean Varieties under Hot Humid Tropical Environment of Ethiopia. Journal of Agronomy and Crop Science 197(1): 67-74.

Mushoriwa, H.(2013).Breeding Gains, Diversity Analysis and Inheritance Studies on Soybean [Glycine max (L.)Merrill] Germplasm in Zimbabwe. A thesis submitted in partial fulfillment of the requirements for the degree of Doctor of Philosophy (PhD) in Plant Breeding, Pietermaritzburg, Republic of South Africa.

Nath, A., A. P. Karunakar, A. Kumar and R. K. Nagar,(2017).Effect of sowing dates and varieties on soybean performance in Vidarbha region of Maharashtra, India. Journal of Applied and Natural Science 9 (1): 544 - 550.

National Meteorological Agency.(2019). Ethiopian National Meteorological Agency Asossa Branch Directorate (NMA) (Unpublished source).

Nekemte Soil laboratory.(2018). Oromia Agricultural Research, Nekemte Soil Lab. http://iqqo.org/

Ohyama, T., R. Minagawa, S. Ishikawa, M. Yamamoto, Van Phi Hung N, N. Ohtake, K. Sueyoshi, T.Sato, Y. Nagumo and Y. Takahasi.(2013)..Soybean Seed Production and Nitrogen Nutrition. In: Board J (Ed.), A Comprehensive Survey of International Soybean Research Genetics, Physiology, Agronomy and Nitrogen Relationships, In Tech, DOI: 10.5772/52287.

O'Keefe, S., L. Bianchi and J.Sharman. (2015).Soybean nutrition. SM Journal of Nutrition and Metabolism, 1(2):1006.

Popovic, V., J. Miladinovic, M. Malesevic., V.Maric., L.Zivanovic.(2013), Effect of agro-ecological factors on variations in yield, protein and oil contents in soybean grain. Romanian Agricultural Research, Nardi Fundulea, Romania. No. 30, DII 2067-5720 RAR 207.

SAS.2004. Statistical Analysis Software version 9.0, SAS Institute Inc. Cary, NC, USA.

Smith, K.J. and W.Huyser.(1987). World distribution and significance of soybean. Agronomy.

Sobko, O., J. Hartung., S.Zikeli., W. Claupein and S. Gruber. (2019). Effect of sowing density on grain yield, protein and oil content and plant morphology of soybean (Glycine max L. Merrill).Plant Soil Environment, 65: 594-601.

Suhre, J.J, N.H.Weidenbenner,S.C. Rowntree, E.W.Wilson, S.L.Naeve, Shawn P. Conley, Shaun N. Casteel, Brian W. Diers, Paul D. Esker, James E. Specht, Vince M. Davis (2014) Soybean yield partitioning changes revealed by genetic gain and seeding rate interactions. Agronomy and Plant Genetics 106(5): 1631-1642.

Thandiwe, N. and Schutte Matthew, (2018). Row Spacing and Seeding Rate Effects on Soybean Seed Yield.DOI: http://dx.doi.org/10.5772/intechopen. 80748

Vanlauwe, B., J. Mukalama, R. Abaidoo and N. Sanginga.(2003). Soybean varieties, developed in West Africa, retain their promiscuity and dual- purpose nature under Highland Conditions in Western Kenya. Innovations as Key to the Green Revolution in Africa; pp. 134-144.

Waswa, W.W.(2015).Evaluation of Yield Potential and Management Practices Affecting Soybean Production in Western Kenya. A Thesis Submitted in Partial Fulfillment of the Requirements for The Degree of Master of Science in Agronomy, University of Eldoret, Kenya.

Wondimu Bekele, Ketema Belete, Tamado Tana (2016). Effect of Soybean Varieties and Nitrogen Fertilizer Rates on Yield, Yield Components and Productivity of Associated Crops Under Maize/Soybean Intercropping at Mechara, Eastern Ethiopia. Agriculture, Forestry and Fisheries 5(1): 1-7. 